\title{
Influence of patient satisfaction through commitment to loyalty inpatient HOSPITALS Jayapura
}

\author{
Bambang Setyajidi \\ Universitas Cenderawasih (UNCEN) Papua \\ B. Kambuaya \\ Universitas Cenderawasih (UNCEN) Papua \\ Ruben Tuhumena \\ Universitas Cenderawasih (UNCEN) Papua \\ Elita Bharanti \\ Universitas Cenderawasih (UNCEN) Papua
}

\begin{abstract}
ABSTRAK
The study was done at the Jayapura Public Hospital Area. The number of respondents was 294 patients. Variable measurement research done using multiple indicator, then analyzed usng structural equation model (Structural Equation Modeling) software with AMOS, and SPSS. Ver. 21. The findings of this study are: Patient satisfaction is positive and significant effect against the commitment of the Patient; The patient's commitment to a positive and significant effect against Patient Loyalty. Furthermore, satisfaction, confidence, and commitment are positioned as the mediation between the variable quality of service with loyalty. So, orisinilitas findings in these studies is variable commitment as mediation of service quality, customer satisfaction, loyalty and confidence. In General, the findings of this study provide strong support against the role of commitment required in building long term relationships and provide strong support for the mediation mechanism.
\end{abstract}

Keyword: Patient Satisfaction, Patient Commitment, Loyalty, Patients, General Hospital Area Of Jayapura.

\section{BACKGROUND}

Customer satisfaction is one of the main objectives of the company in the conduct of its business ((Ardianto, 1996); (Levesque 2000, \& McDougall)), a company engaged in the service industry or manufacturing industry (Ghobadian, et al. 1994). The concept of marketing is expressly stated that the key in achieving the goal of a company is how to satisfy customers more effectively than what is done by the competitor (ardianto,1996). Naser, Jamal, and AlKhatib (1999), States that customer satisfaction is the basis for the success of the company, especially in conditions of intense competition.

The underlying thought about the meaning of customer satisfaction is a customer who is satisfied with a product and/or services provided will have the possibility to make purchases, trying products and/or services to other the company offered, preaching the superiority of products and/or services of the company to another party (the positive word of mouth) and skew loyal to the company (Anderson, et al. 1994); (Andreassen \& Lindestad, 1998); (Bowen \& Chen, 2001); (Naser etal., 1999); (Söderlund, 1998). Many empirical studies have been conducted to identify any factors that are thought to affect the level of customer satisfaction. 
Naser et al. (1999), argues thatcustomer satisfaction depends on the quality of a product. Similarly, results of research and Lindestad Andreassen prove product quality affects the level of satisfaction (Hadi, 2002). Meanwhile, many experts (Anderson et al., (1994); Cronin \& Taylor, (1992); Fornell et al., (1996); McDougall \& Levesque, (2000); Naumann, et al. (2001); Parasuraman, et al. (1988); Selnes (2013), stating that the quality of service is the determinants of customer satisfaction.

Commitment defined by Moorman, et al. (1992), the relationship between attitude toward physical evidence, processes and employees with quality of connectedness, as well as its role in inflicting repeated intention to purchase and loyalty. In this case emphasized that the commitment is an element behavior as an attempt to maintain and safeguard the long-term relationship between the two sides in order to make this relationship more meaningful. A commitment will not occur if one or both parties feel that the relationship is not profitable. In other words the commitment means in it there is a valuable relationships that need to be maintained constantly, where each side is willing to work together to maintain this relationship.

Commitment to relate (relationship commitment) is defined as the seriousness to keep an already agreed upon based on the whims and kesedian explicitly or implicitly between Exchange partners (customers and service providers)for continued functional relationship already entwined (Dwyer et al.,1987). Schnaars in Tjiptono (1997), stating that, customer satisfaction is essentially the purpose of a business. Creation ofcustomer satisfaction may provide some benefits, such as the relationship between the company and its customers be harmonious, as well as providing a good basis for the purchase and the creation of customer loyalty. It is worth to note, that customer satisfaction is a long-term strategy that requires commitment, either human resources or funds which in turn can foster customer loyalty (Schnaars, in Tjiptono, 1997).

Satisfaction was positively associated with the intention of buying it back, wishes to recommend goods and services, loyalty and also profit. (Anderson and Fornell, (1994); Anton (1996); Bitner (1990) in Sivadas and Baker-Prewitt (2000). In relation to customer loyalty, Anderson \& Fornell, (1994), stating that if customers are satisfied against goods or the quality of the services provided, it will engender customer loyalty. Loyalty means the ability of a company positioned its products in the minds of customers, which the company considers the customers as partners by means of stabilizing the confidence of customers, always interact, when necessary, in order to develop joint progress ( Kartajaya, 1999). Whereas the definition of a customer loyal or faithful is someone who performs repeated use of the same company, notify to the other potential customers, Word of mouth, and it became an antidote to attacks from rival (Evans \& Laskin, 1994). So it can be said that the success of a company is highly determined by the loyalty of its customers. Based on the description above, this research did a study on the influence of service quality, satisfaction, confidence, commitment to patient loyalty General Hospital area of Jayapura. The election of the Regional General Hospital as an object of research is based on the consideration that the patients who visit a lot more compared to other hospitals so that patients ' perception is more diverse, even though the patient is free to choose the place medical treatment in accordance with the patient's own choice, based on the quality of which is considered appropriate and satisfactory.

This research was also effected on the importance of the PROVINCIAL HOSPITAL in Jayapura to do improvements in dealing with the condition of the development of science and technology which are very rapidly, as well as the demands of the Ministry that the better. With regard to the concept of service quality, patient satisfaction, patient trust, commitment and loyalty of the 
patient to be achieved, the PROVINCIAL HOSPITAL in Jayapura as one hospital seeks to provide the best quality of service, because the Manager realize that it is a very valuable asset. This study mainly dotted decline from the existence of the phenomenon and the gap-the gap theory and the empirical findings are inconsistent regarding the variables of the study, especially to the satisfaction and confidence. A real phenomenon from observational results found yet functioning effectively in improving the quality of the Organization and to ensure the achievement of the goals of the organization.

The problems faced by HOSPITALS in Jayapura is still existence of patients who are not satisfied because of the deficiencies that exist even though it has been and will continue to be addressed. It was necessary to get the existence of review factors that influence on satisfaction, trust and commitment in enhancing patient loyalty of patients. After going through the literature review, it is hypothesized that the variable quality of service i.e., realibility, responssiveness, assurance, empathy and tangibles effect on customer satisfaction. Further hypothesized that the quality of services to the satisfaction of the patient, the patient's confidence and commitment to patient loyalty.

\section{Consumer satisfaction}

\section{EXAMINATION THEORY}

The concept of what exactly is Consumer/customer satisfaction has been expressed by many experts. Nasution (2004), quoting Tse and Wilton stated that the satisfaction or dissatisfaction of the customer is a customer response towards the evaluation of the discrepancy between perceived diskormasi/hope before (or other performancenorms) and actual performance perceived product after use. While p. Kotler and Armstrong (2004), stating that customer satisfaction is the level of one's feelings after comparing performance or results that he felt compared to the expectation. From some of the above definition, then the authors conclude that customer satisfaction is a condition in which state it was received by the customers of the products that he can, as he would expect from the product. When associated with the company's institutions, then what can be obtained by the user community the company, in accordance with what he would expect from the company.

Kotler, et al. (1995), identify the 4 methods to measure customer satisfaction, namely as follows: the system of complaints and suggestions, Ghost Shopping, Lost Customer Analysis and customer satisfaction Survey

\section{The commitment}

Commitment to relate (relationship commitment) is defined as the seriousness to keep an already agreed upon based on the whims and kesedian explicitly or implicitly between Exchange partners (customers and service providers) for continued functional relationship already entwined (Dwyer et al.,1987). Functional relationship was transactional relationship between customers and service providers. According to Morgan And Hunt (1994), the focus of the definition is the desire to maintain the commitment of participation between customers and service providers to keep in touch. Kelley et al. (1990), defines the commitments as follows: "the organizational commitment of service is indicative ofthe organization s likehood of developing or maintaining customer identification with the organizational goals and value and retaining the customer service as an active participant in service encounter ". Gundlach, et al. (1995), in the Garbarino and Johnson (1999), explained that this commitment has three components, namely: 1). The components of the instrumental of some form of investment, Component 2). attitudes can be described as affective commitment or attachment psychological, and 3). The temporal dimension that indicates that the relationship occurs in long periods of time. 


\section{Loyalty}

Loyalty will be developed following the three stages, namely the stage of cognitive, affective, and konatif. Consumers are loyal first on kognitifnya, then finally on affective aspect and aspect konatif (Oskamp, 1991 as quoted Dharmmesta (1999): 1. Cognitive. In this case the elements of cognitive aspects of mind and all the processes that occur in it which includes accesibility, confidence, centrality and clarity regarding attitudes towards a product will have an effect on customer loyalty. Customers can easily remember the name of the product and are confident that the products correspond to the value system that is more likely to be adhered being positive and it is important for the formation of customer loyalty. 2. Affective. Emotional conditions (feeling) is a component of customer attitude will establish customer loyalty. Aspects of this include feelings of emotional mood and our satisfaction obtained after using the product will build customer loyalty. 3. Conative. The condition is a trend that is on the customer to perform certain actions. There are three factors that affect the propensity of customers to behave that shows loyalty to a brand that is the cost of passage, hope and sunk cost.

Loyalty in this research is the loyalty in the sense of true loyalty. The indicator used is derived from (Kotler, 2000), Zeithalm, et al. (1998), i.e. a). Do not switch to other hospitals, b). A sense of belonging, c). Recommendations to the other party, d). Commitment, e). Cooperates and f). familiarity

\section{METOLOGI RESEARCH}

This research was conducted using a quantitative approach to answer research questions explained. The approach is performed with the eksplanatori method to examine the relationship of causality between the variables research through hypothesis testing. Eksplanatori research is to analyze the relationship between research variablesand explain the process of how a variable effect on another variable. A quantitative method was chosen because of his ability to generalize the model by using a particular sample. The data obtained should be scalable and can produce a conclusion that can be generalized.

\section{Pupulasi and sample}

Primary data is data obtained directly from the original sources (without going through the intermediary) by using the methods of the survey. Primary data that exist in this research data is taken through a questionnaire of the customer/patient who was elected to the respondent. (Ferdinand, 2014), out of a total population of 1.103 patients in the blurb above, samples taken were as follows:

Where:

$$
\begin{aligned}
& \mathrm{N} \\
& \mathrm{n}=\mathrm{-} \\
& \mathrm{1}+\mathrm{N}(\mathrm{N})^{2}
\end{aligned}
$$

$\mathrm{n}=$ large Samples

$\mathrm{N}=$ Total Population

$\mathrm{d}=$ the specified precision or imprecision due to the looseness prosentasi sampling errors can still be ditolelir or desirable (5\%).

Based on that formula then retrieved the magnitude samples have been admitted in hospital Public Areas doc 2 Jayapura is as follows:

$$
n=\frac{1.103}{1+1.103(0.05)^{2}}=\frac{1.103}{1+2,7575}=\frac{1.103}{3,7575}
$$

$n=293.54$ rounded into 294 respondents. 


\section{Operasionalisasi The Concept.}

\begin{tabular}{|c|c|c|c|c|}
\hline Variabel & Dimensi & Indikator & $\begin{array}{l}\text { Kategori } \\
\text { (Linkert) }\end{array}$ & Item \\
\hline \multirow[t]{4}{*}{$\begin{array}{l}\text { Kepuasan Pasien } \\
\text { (Lupiyoadi, 2008) }\end{array}$} & Kepuasan Pasien & $\begin{array}{l}\text { Terpenuhi harapan pelanggan } \\
\text { secara keseluruhan / overall } \\
\text { satisfaction. }\end{array}$ & $\begin{array}{l}\text { STS-SS } \\
1-5\end{array}$ & $\begin{array}{l}\text { Satis1 } \\
\text { Satis2 }\end{array}$ \\
\hline & & $\begin{array}{l}\text { Perasaan puas menggunakan jasa } \\
\text { pelayanan yang ditawarkan dengan } \\
\text { harapan pelanggan / expectation. }\end{array}$ & & $\begin{array}{l}\text { Expec1 } \\
\text { Expec2 }\end{array}$ \\
\hline & & $\begin{array}{l}\text { Kepuasan terhadap fasilitas selama } \\
\text { menjalin hubungan de-ngan } \\
\text { perusahaan / experience. }\end{array}$ & & $\begin{array}{l}\text { Exper1 } \\
\text { Exper2 }\end{array}$ \\
\hline & & $\begin{array}{l}\text { Kepuasan terhadap peralatan yang } \\
\text { tersedia. }\end{array}$ & & $\begin{array}{l}\text { Tool1 } \\
\text { Tool2 }\end{array}$ \\
\hline \multirow{4}{*}{$\begin{array}{l}\text { Komitmen Pa- } \\
\text { sien. (Morgan \& } \\
\text { Hunt, 1994) }\end{array}$} & $\begin{array}{l}\text { Komitmen } \\
\text { Pasien }\end{array}$ & Perasaan bangga menjadi pasien. & $\begin{array}{l}\text { STS-SS } \\
1-5\end{array}$ & $\begin{array}{l}\text { Bangga1 } \\
\text { Bangga2 }\end{array}$ \\
\hline & & Perasaan memiliki. & & $\begin{array}{l}\text { Milik1 } \\
\text { Miilk2 }\end{array}$ \\
\hline & & $\begin{array}{l}\text { Perhatian terhadap keberhasilan } \\
\text { jangka panjang. }\end{array}$ & & $\begin{array}{l}\text { Hasil1 } \\
\text { Hasil2 }\end{array}$ \\
\hline & & Menjadi pendukung setia. & & $\begin{array}{l}\text { Dukung1 } \\
\text { Dukung2 }\end{array}$ \\
\hline \multirow[t]{6}{*}{$\begin{array}{l}\text { Loyalitas Pasien. } \\
\text { (Gremler \& } \\
\text { Brown, 1996) }\end{array}$} & Loyalitas- Pasien & Tidak beralih ke rumah sakit lain. & $\begin{array}{l}\text { STS-SS } \\
1-5\end{array}$ & $\begin{array}{l}\text { Setia1 } \\
\text { Setia2 }\end{array}$ \\
\hline & & Pasien mengatakan hal positif. & & $\begin{array}{l}\text { Pos1 } \\
\text { Pos2 }\end{array}$ \\
\hline & & Rekomendasi kepada pihak lain. & & $\begin{array}{l}\text { Rek1 } \\
\text { Rek2 }\end{array}$ \\
\hline & & $\begin{array}{l}\text { Kemungkinan pasien akan kembali } \\
\text { jika sakit. }\end{array}$ & & $\begin{array}{l}\text { Rutin1 } \\
\text { Rutin2 }\end{array}$ \\
\hline & & $\begin{array}{l}\text { Merupakan pilihan pertama jika } \\
\text { memerlukan perawatan. }\end{array}$ & & $\begin{array}{l}\text { Pilih1 } \\
\text { Pilih2 }\end{array}$ \\
\hline & & $\begin{array}{l}\text { Percaya bahwa diberikan perawatan } \\
\text { terbaik. }\end{array}$ & & $\begin{array}{l}\text { Max1 } \\
\text { Max2 }\end{array}$ \\
\hline
\end{tabular}

\section{Data analysis techniques}

Analytical techniques used to interpret and analyze the data in accordance with models designed in this study i.e. designing variables into two forms namely latent variable/construct (unobserved variable) and the manifest variables (observed variable).Latent variables (unobserved variable) is a variable that cannot be measured directly, so it takes some indicators to measure it. While the manifest variables (observed variable) is a variable that can be measured or is an indicator of latent variables. Therefore the analysis techniques used in this research is the Structural Equation Modelling (SEM) in the form of AMOS Version 21.

\section{RESULTS AND DISCUSSION}

Based on the results of estimation Coefficients table Line and statistical tests can be seen the results of hypothesis testing showed that the influence of the quality of service (TOS) against Patient Loyalty (LP) indicated by the value of 0.764 line coefficientwith a value of $\mathrm{C}$ r. of 13.862 and p-value of 0.000 . Because the value of $\mathrm{P}(0.000)<0.05$ and $\mathrm{c}$. R of $13.862>1.960$ then H4 accepted. So it can be concluded that the quality of service (TOS) effect significantly to Patient Loyalty (LP). The great influence of the quality of service (TOS) against Patient Loyalty (LP) of 
0.764. Line represents the positive sign of the coefficient means that if the quality of service (TOS) increased Patient Loyalty then (LP) will also experience increased.

Based on calculations presented at the Mediation table Testing Effect can be noted that the direct influence of the quality of service (TOS) against Patient Loyalty (LP) of0.764. Indirect influence through Patient Satisfaction (KPs), Patient Trust (KPc) and the commitment of the patient (KMm) of 0.181 . So the obtained total influence of quality of service (TOS) against Patient Loyalty (LP) through Patient Satisfaction (KPs), Patient Trust (KPc) and the commitment of the patient (KMm) of 0.945 . From the results it can be noted that the influence of the total quality of service (TOS) against Patient Loyalty (LP) through Patient Satisfaction (KPs), Patient Trust (KPc) and the commitment of the patient (KMm) of 0.945 higher than direct influence the quality Service(TOS) against Patient Loyalty (LP) of 0.764. This indicates that the Patient Satisfaction (KPs), Patient Trust (KPc) and the commitment of the patient $(\mathrm{KMm})$ contributing positively under the influence between the quality of service (TOS) against Patient Loyalty (LP). the great influence of the total of 0.945 marked positive which means the higher quality of service (TOS) which mediated Patient Satisfaction (KPs), Patient Trust (KPc) and the commitment of the patient (KMm) will increase Patient Loyalty (LP).

In accordance with research findings Caruana (2002), Bloemer, Ruyter, and Peeters (1998), Bei and Chiao (2001), Jahroni (2009), Gefen (2002), Setiawan (2007), great (2006), Hazra and Srivastava (2009), Sarwar et al. (2012), Djohan, (2015), Subiyantoro, (2012). Not in accordance with research findings from Halim et al. (2014), Montana and Massie (2015). Significant influence on the quality of service against the loyalty of patients due to the patient's perception of the quality of health services at the PROVINCIAL HOSPITAL in Jayapura from the aspect of physical evidence, reliability, responsiveness, assurance and empathy is good, giving rise to the attitude of love, glad, Jayapura, against HOSPITALS. It is revealed in the interview that was done with some patients, where it is known that the interview of services that patients treated at HOSPITALS during the experience the Jayapura already higher quality from a bygone time. The results of the interviews in line with theories about the quality of service stating that the kualtas service is a comparison between the perceptions and expectations of consumers about the service.

Service quality is also the result of a process of evaluation, which consumers compare the harapan-harapannya with the service that he feels and thank. A good quality of service will create loyalty is defined as juice, happy, love, as well as of an object. So,the feeling of love and happy against the PROVINCIAL HOSPITAL in Jayapura due tothe perceived service quality enough patients. Therefore, patients have few times consume health services at the PROVINCIAL HOSPITAL in Jayapura, as well as assume that low price is paid to the services patients received is in accordance with the perceived quality of service.

Research findings suggesting that patient satisfaction is not significant effect against patient loyalty, illustrate that the changes on patient loyalty is not necessarily caused by changes in satisfaction. Trust the patient does not significantly affect the commitment of the patient, the patient's trust is by no means negligible in serving the patients hospitalization, as besides the PROVINCIAL HOSPITAL in Jayapura there is also a private hospital can be an alternative service options health. Although not significantly affect patient satisfaction loyalty, but the satisfaction of influencing the commitment of the patient, the patient's beliefs did not significantly affect the commitment of the patient, but the patient's beliefs influence patient loyalty. Therefore, the management of the hospital will need to keep the quality of services provided are the same in all care units. 


\section{Conclusion}

\section{CONCLUSIONS AND SUGGESTIONS}

Patient satisfaction the significant effect against the Commitment of the patient. The line coefficient represents a positive sign means that if a patient Satisfaction increased then the patient's Commitment will also experience increased.

Patient satisfaction was not significant effect directly or indirectly through a commitment to Patient Loyalty. From the results it can be noted that the influence of the total Satisfaction of the patient against Patient Loyalty through commitment to patients, higher than direct influence satisfaction of the patient against Patient Loyalty. This indicates that the patient's Commitment to contribute positively in the influence between the satisfaction of the patient against Patient Loyalty. The great influence of the total marked a positive which means the higher the Satisfaction of patients will improve Patient Commitment mediated Loyalty Patients but not significant.

\section{Advice}

To keep a quality service and satisfying and trustworthy that fosters patient commitment then: 1. Suggestions for the doctor's primary care providers and treatment of patients in inpatient installation such as: Duty based on standards such as: the granting of service to patients is the main thing, treating each patient with courtesy and of course, respect privacy and honor patients, listening to and respecting the views of patients, providing information that can be understood, patients aware of various limitations,honest and trustworthy, prevent patients from physical and financial risk due to medical action, in cooperation with the colleagues for the good of the patients treated.

2. Suggestions for management of the PROVINCIAL HOSPITAL in Jayapura of which are:

1) trying to figure out the patient's wishes by doing survey, survey satisfaction needs service and health service utilization rate survey of hospital; 2) ensure that procedures and standards have been drawn up and implemented properly. 3) Establish good communication with patients in order to socialize the Service-service that is capable of is given by the hospital, for example by making brochures-brochures, information desk, computer terminals that can be accessed by the patient; 4) draw up and enforce a system of supervision and monitoring of health services provided effectively; 5) Menginvetarisir the root cause of the problem of internal factors that affect the quality of health services and administration, especially in the areas of: HUMAN RESOURCES, the education factor a factor of additional training and knowledge, working period and Long Term, faktot workload, facilities and equipment, the Standard Operating Procedure and work instructions, administrative and service flow factors, factors of control and evaluation, management factors of hospitalization and medical staff functional factors.

\section{BIBLIOGRAPHY}

Agung, K. H. (2006). Analisis Pengaruh Kualitas Layanan, Komitmen Dan Kepercayaan Terhadap Loyalitas Konsumen (Studi Kasus Pada Nasabah Tabungan Simpeda Bank Jateng). program Pascasarjana Universitas Diponegoro.

Anderson, E. W., Fornell, C., \& Lehmann, D. R. (1994). Customer satisfaction, market share, and profitability: Findings from Sweden. The Journal of Marketing, 53-66.

Anton, J. (1996). Customer relationship management: making hard decisions with soft numbers: Purdue Univ Pr.

Ardianto, E. (1996). Mengelola Nilai Konsumen Untuk Mencapai Kepuasan Konsumen. Paper presented at the Jakarta, Forum Manajemen Prasetya Mulya.

Arikunto, S. (2001). Prosedur Penelitian Suatu Pendekatan Pendek Edisi Revisi: Jakarta: Rineka Cipta. 
Bitner, M. J., Booms, B. H., \& Tetreault, M. S. (1990). The service encounter: diagnosing favorable and unfavorable incidents. The Journal of Marketing, 71-84.

Caruana, A. (2002). Service loyalty: The effects of service quality and the mediating role of customer satisfaction. European Journal of Marketing, 36(7/8), 811-828.

Cronin Jr, J. J., \& Taylor, S. A. (1992). Measuring service quality: a reexamination and extension. The Journal of Marketing, 55-68.

Dharmmesta, B. S. (1999). Loyalitas Pelanggan: Sebuah Kaman Konseptual Sebagai Panduan Bagi Peneliti. Jurnal Ekonomi dan Bisnis Indonesia, 14(1999).

Evans, J. R., \& Laskin, R. L. (1994). The relationship marketing process: A conceptualization and application. Industrial Marketing Management, 23(5), 439-452.

Ferdinand, A. (2014). Metode Penelitian Manajemen. Edisi Kelima: Semarang: Badan Penerbit Universitas Diponegoro.

Gefen, D. (2002). Customer loyalty in e-commerce. Journal of the association for information systems, 3(1), 2.

Gefen, D., Karahanna, E., \& Straub, D. W. (2003). Trust and TAM in online shopping: an integrated model. MIS quarterly, 27(1), 51-90.

Ghobadian, A., Speller, S., \& Jones, M. (1994). Service quality: concepts and models. International Journal of Quality \& Reliability Management, 11(9), 43-66.

Hadi, S. B. (2002). Analisis Faktor-faktor yang Menentukan Kepuasan Pelanggan dan Pengaruhnya Terhadap Loyalitas Pelanggan. (Tesis, Tidak Dipublikasikan, Program Magister Manajemen Universitas Diponegoro, Semarang.).

Halim, P., Swasto, B., Hamid, D., \& Firdaus, M. R. (2014). The Influence of Product Quality, Brand Image, and Quality of Service to Customer Trust and Implication on Customer Loyalty (Survey on Customer Brand Sharp Electronics Product at the South Kalimantan Province).

Hazra, S. G., \& Srivastava, K. B. (2009). Impact of service quality on customer loyalty, commitment and trust in the Indian banking sector. IUP Journal of Marketing Management, 8(3/4), 74.

Jahroni. ( 2009). Pengaruh Kualitas Layanan Terhadap Loyalitas Nasabah Melalui Kepuasan, Komitmen, Kepercayaan Pada Bank Central Asia Tbk. JAMBSP, Vol. 5 (No. 3).

Kartajaya, H. (1999). Bridging to the network Company: Transformasi Pos Indonesia Menuju Perusahaan Kelas Dunia.

Kelley, S. W., Donnelly Jr, J. H., \& Skinner, S. J. (1990). Customer participation in service production and delivery. Journal of Retailing, 66(3), 315.

Kotler. (2000). Marketing management. Millennium edition (10th edition) p, 10.

McDougall, G. H., \& Levesque, T. (2000). Customer satisfaction with services: putting perceived value into the equation. Journal of Services Marketing, 14(5), 392-410..

Morgan, R. M., \& Hunt, S. D. (1994). The commitment-trust theory of relationship marketing. The Journal of Marketing, 20-38.

Naser, K., Jamal, A., \& Al-Khatib, K. (1999). Islamic banking: a study of customer satisfaction and preferences in Jordan. International Journal of Bank Marketing, 17(3), 135-151.

Nasution, M. N. (2004). Manajemen Jasa Terpadu. Bogor: Ghalia Indonesia.

Parasuraman, A., Zeithaml, V. A., \& Berry, L. L. (1988). Servqual. Journal of Retailing, 64(1), 12-40.

Selnes, F. (2013). An examination of the effect of product performance on brand reputation, satisfaction and loyalty. Journal of Product \& Brand Management.

Setiawan, M. B. (2007). Pengaruh Kualitas Layanan, Kepercayaan dan Komitmen Terhadap Loyalitas Nasabah (Studi pada PD. BPR Bank Pasar Kendal). Jurnal Bisnis dan Ekonomi, 14(2).

Setiawan, M. B., \& Ukudi. (2007). Pengaruh Kualitas Layanan, Kepercayaan dan Komitmen Terhadap Loyalitas Nasabah (Studi pada PD. BPR Bank Pasar Kendal). Jurnal Bisnis dan Ekonomi, 14(2).

Subiyantoro. (2012). Pengaruh Kualitas Layanan, Kepercayaan, Kepuasan Mahasiswa Terhadap Minat Berperilaku (Wom) Mahasiswa. OSIT(SNASTI), 43-52. 
Setyajidi, B., Kambuaya, B., Tuhumena, R., \& Bharanti, E. (2018). Influence of patient satisfaction through commitment to loyalty inpatient HOSPITALS Jayapura. Advances in Social Sciences Research Journal, 5(4) 370-378.

Sukmawati, \& Massie, J. D. D. (2015). Pengaruh kualitas pelayanan terhadap loyalitas pelanggan dan dimediasi kepercayaan dan kepuasan. Jurnal EMBA 732 No.3, 3 729-742.

Tjiptono, F. (1997). Strategy Pemasaran, penerbit: Andi offset. Edisi Kedua, Cetakan. 